\title{
Does Accounting Influence Finance? The Case of IFRS 9 and Fuel Hedging
}

\author{
Francesco Bellandi ${ }^{1}$ \\ ${ }^{1}$ Head of Technical Accounting, Multinational, London, UK \\ Correspondence: Francesco Bellandi, Head of Technical Accounting, Multinational, London, UK. E-mail: \\ Francesco_bellandi@yahoo.com
}

Received: October 4, 2021

Accepted: November 6, 2021

Online Published: November 12, 2021

doi:10.5539/ijbm.v16n12p1

URL: https://doi.org/10.5539/ijbm.v16n12p1

\begin{abstract}
Finance does influence accounting, for example it is known that hedge accounting under International Accounting Standards Board (IASB) (2019), IFRS 9 has been more aligned to risk management practice. Although, as commonly held, accounting represents the substance of economic events without modifying them, opportunities offered by a new accounting standard may affect finance strategies. This paper studies how the IASB (2019), IFRS 9 hedge accounting requirements versus IASB (2014), IAS 39 have modified fuel hedging practice for a sample of IFRS airlines. Hedge accounting under the new standard results to have been adopted by a very large proportion of the sample. Its new features of risk component hedges, accounting for time value of option, forward points, or basis spread in other comprehensive income (hereafter, OCI), and simplified effectiveness assessment have been exploited by most of the sampled companies, although a definite explanation as an accounting strategy is only partially disclosed. In a context where fuel cost is one, if not the most significant caption of operating expenses of airlines, IASB (2019), IFRS 9 has provided an incentive to expand the use of fuel hedging, at least for accounting purpose.
\end{abstract}

Keywords: IFRS 9, fuel hedging, airline

\section{Introduction}

This paper studies how IFRS financial statement preparers have applied the IASB (2019), IFRS 9 hedging requirements to fuel hedging. Fuel hedging is an established practice by airlines, to mitigate the increase in cost of fuel and its volatility, considering that fuel cost has a substantial impact on an airline income statement, as it represents one, if not the largest operating expense item. Different techniques may be employed for fuel hedging. A purchased call option gives an airline a right to exercise that option in the future and purchase a specified quantity of oil at a specific price agreed at the contract date, which it will do if the then current price is higher than the strike price of the call option plus the premium of the option. If the company expects a decline in the oil price, it may sell a put option, giving the counterparty a right to sell in the future at the contracted price. In a collar, a company establishes a maximum and a minimum price band through a call option (cap) and a put option (floor). Through the call option the company is protected against increase of the fuel price. Through the put option the company is protected against the cost of the call option under certain circumstances. Through a forward contracted directly with a commodity provider or as an over the counter (OTC) instrument through investment banks, two parties exchange, by means of net settlement of the difference between the contracted forward price and the spot price at settlement date, an underlying asset amount at a specific price on a specific date. If the spot price is higher, the airline gains, vice versa it loses in the opposite situation. Through a fixed-rate swap with an investment bank, a company can take a fixed price versus a floating rate over the contract duration. Future contracts offer similar economics, but they are standardized contracts that are exchanged on regulated commodity exchanges and require a deposit into a margin account with a clearinghouse.

IASB, IFRS 9 in its 2014 version became effective on 1 January 2018. The standard, inter alia, amends hedge accounting, and so ultimately affects the accounting for fuel hedging. Fuel is not a financial asset or liability. Under IASB (2014), IAS 39, paras. 82, AG100, BC137-BC138, IG.F.6.2, a nonfinancial asset or a nonfinancial liability could not be designated as a hedged item, except for hedging foreign currency risk or when designated as a hedged item in its entirety for all risks. Therefore, IASB (2014), IAS 39 did not permit hedge accounting for a risk portion 
other than foreign currency risk, even if that risk component was contractually specified. An ingredient or component of a nonfinancial asset or liability could not be designated as a hedged item. The rationale was both the difficulty to isolate and measure the appropriate portions of changes in fair value or cash flows variability concerning such risk portions, the lack of ability to measure effectiveness, and a danger of circumventing the effectiveness testing requirements. However, a hedging relationship where a nonfinancial hedging instrument had different terms from the underlying nonfinancial asset or liability that was hedged in its entirety could qualify if all the requirements for hedge accounting, including expectation of high effectiveness were met. IASB (2019), IFRS 9 removes the assumption in IASB (2014), IAS 39 that the entire item is the default unit of account as a hedged item. In fact, under IASB (2019), IFRS 9, paras. 6.3.7, B6.3.8, an entity can designate as a hedged item changes in the fair value or cash flows of a financial or nonfinancial item that within the context of the particular market structure are attributable to a separately identifiable and reliably measurable risk component (including one-side risk of that risk component), where the changes in cash flows or fair value of the item that are attributable to that risk component are reliably measurable. Also, one or more selected contractual cash flows, or components of a nominal amount may be hedged items. Risk components may be either contractually specified or noncontractually specified. The existence of a market for gas oil forward contracts entails that the gas oil price exposure is reliably measurable (IASB 2019, IFRS 9, para. B6.3.10). The standard gives an example concerning hedging future jet fuel purchases, consisting in crude oil contracts for consumption forecast for 12-24 months before delivery, gas oil derivatives for 6-12 months, and jet fuel contract for up to 6 months. The entity identifies two non-contractual risk components: crude oil price risk based on Brent crude oil and gas oil price risk. IASB (2019), IFRS 9, para. B6.3.25 explains by means of example related to benchmark crude oil that the cash flows of a designated hedged component must be lower than or equal to the total cash flows of the entire item.

Under U.S. GAAP, Financial Accounting Standards Board (FASB) (2017), ASU 2017-12 also permits hedge accounting for risk components, deleting the previous requirement that only the overall variability in cash flows or related to foreign currency risk could be designated as the hedged risk in a cash flow hedge of a nonfinancial asset (FASB, 2020, FASB ASC 815-20-25-15(i)(3)). However, unlike IASB (2019), IFRS 9, such a risk component can only be the variability in cash flow changes attributable to changes in a contractually specified component (FASB 2017, ASU 2017-12, paras. BC58-BC59). In addition, there is no such a concession for the purpose of fair value hedges of a nonfinancial asset or liability, as FASB (2020), FASB ASC 815-20-25-12(2). (2).(e) requires that the designated risk being hedged be the risk of changes in the fair value of the entire hedged asset or liability reflecting its actual location of a physical asset. Therefore, an entity cannot designate the risk of changes in the price of crude oil in a fair value hedge of gasoline because the price risk of a similar asset in a different location or of a major ingredient is not the hedged risk. Under IASB (2019), IFRS 9, para. 6.5.11, an entity accounts for a cash flow hedge by recognizing certain amounts in cash flow hedge reserve in OCI: in relation to the hedged item, the lower of the cumulative gain or loss from inception of the hedge on the hedging instrument or the present value of the cumulative change in the hedged item; and, in relation to the hedging instrument, its effective portion of gain or loss. Any remaining gain or loss is considered as hedge ineffectiveness to be recognized in profit or loss. In a cash flow hedge, in the case of a nonfinancial asset or liability that results from the hedged forecasted transaction, the entity subsequently reclassifies the amount accumulated in the cash flow hedge reserve in the carrying amount of that asset or liability. Under IASB (2019), IFRS 9, para. 6.5.8, in a fair value hedge, an entity recognizes a gain or loss on the hedging instrument in profit or loss and adjusts the carrying amount of the hedged item against profit or loss for hedging gain or loss on the hedged item.

To apply IASB (2014), IAS 39 hedge accounting to fuel hedging, a company had to hedge the entirety of risk related to the fuel purchase. However, a hedging instrument that fully reflects this type or risk is generally not available. Not all jet fuel futures contracts are traded in different geographies and using other markets like Tokyo Commodity Exchange (TOCOM) introduces foreign currency risk, for example for Yen-denominated short-term jet fuel futures. Using crude or heating oil futures, for example on the NYMEX, is a proxy for jet fuel. The result is that hedging would have some accounting ineffectiveness, might not qualify for hedge accounting due to ineffectiveness, or discourage the use of hedge accounting as too complicated. While a company may anyway decide to hedge from a risk management perspective to stabilize its cash flows, improve budget accuracy, reduce costs over the contract period, and take advantage of investment opportunities, a failure to account for hedge for accounting purposes would not reach elimination of profit or loss mismatch in the financial statements. The IASB explains that companies have claimed issues with the IASB (2014), such as the IAS 39 prohibition on risk component hedges, the fact that in certain situations there may be a lack of appropriate hedging instrument for the entire item, it may be cheaper to hedge a risk component, only some portions may need to be hedged, different benchmarks may be used as applicable to a specific geographical area or because more liquid (IASB 2019, IFRS 9 , paras. BC6.175, BC6.188). 
From all the above it is evident that IASB (2019), IFRS 9 has changed the rules of the game for fuel hedging, and a question arises as to how airlines have reacted in their fuel hedging as well as hedge accounting practices.

As better illustrated in the next paragraph, the present scholarship has devoted most efforts to the economic perspective of the phenomenon examined, that is, whether fuel hedging is advantageous and under what circumstances. Key contributions from the accounting perspective relate to the accounting incentives and disincentives under prior standard IAS 39. A research gap exists as to the effects of IFRS 9 on fuel hedging. The findings of this article may address such a gap as the present study specifically addresses whether and how companies have modified their fuel hedging practice in reaction to IFRS 9 and whether the new standard has been interpreted as an opportunity in this regard. Readers can benefit from this study to become aware of the opportunities offered by IFRS 9 as a driver of fuel hedging for accounting purpose and better articulate their risk management and related accounting strategy. Researchers can also move from this work to device additional surveys to explore company's proactive hedging strategies that capture the opportunities offered by IFRS 9 .

\section{Literature Review}

Fuel hedging has been scrutinized from an economic perspective, often blamed for not having a sound theoretical or statistical justification. Morell et al. (2006) investigates the rationales for fuel hedging and how the relationship between oil prices and travel demand cycles may or may not justify it, concluding that in most of the cases the outcome depends on the timing of airline cycles and psychology of markets. By analyzing U.S. major airlines in the period 1996-2005, Trempski (2009) concludes that fuel hedging is not valued by stock investors as reflected in the price of the stock as they can reduce their portfolio risk by diversification. Hoon Lim et al. (2014) find that, although in 2000-2012 U.S. airlines hedging fuel have 9-12\% lower operating costs, this is statistically irrelevant as a similar result may be obtained without such a practice by increasing efficiency. On the other hand, in studying 28 U.S. airlines during the period 1992-2003, Carter et al. (2006) find a positive relation between fuel hedging and firm value, increasingly with the proportion hedged, which they in part explain with the opportunity to use up investment opportunities. Korkeamäki et al. (2016) report a positive relationship between hedging and firm value, especially with passive management hedging strategies and under managerial ownership. Duran et al. (2017) find that for U.S. major passenger airlines there is a statistically significant long-term positive relationship between fuel hedging and firm value. Hoon Lim et al. (2016) investigate the effects of duration and futures contract maturity on the effectiveness of fuel hedging.

From an accounting perspective, Cominskey et al. (2008) find that entities may decide not to designate derivatives for accounting purposes because of the significant cost of documentation and monitoring, the use of natural hedges, even for accounting, absence of qualifying hedges, and increase risk of restatement. Glaum et al. (2011) find that IAS 39 has influenced hedging behaviors. Presence in more mature markets, leverage, dispersion of ownership, growth opportunities, and profit-oriented strategies are positively correlated with the use of IAS 39 hedge accounting. Bernhardt et al. (2016) compare IASB (2019), IFRS 9 to IASB (2014), IAS 39 hedge accounting in general.

Irrespective to whether entities decide to hedge, accounting standards may or may not permit the change in the hedging instrument carrying amount to neutralize the change in the hedged item in the financial statements. IASB (2019), IFRS 9 is a recent phenomenon, therefore this article seeks to fill part of the gap in academic research on the impact of that standard to fuel hedging.

\section{Research Method and Hypotheses Development}

As explained in the introduction, IASB (2014), IAS 39 did not permit component risk hedging. Therefore, the research question is whether the IASB (2019), IFRS 9 amendments to hedge accounting have provided airlines with an additional opening to forms of fuel hedging that were previously not permitted by IASB (2014), IAS 39, and have provided with an incentive to broaden the application of fuel hedging, and whether airlines have been receptive of such an additional opportunity.

A first hypothesis that the study intends to test is that, although the adoption of the new hedging accounting under IASB (2019), IFRS 9 was not mandatory on first adoption of the standard (the standard permits an entity to carry on IASB, 2014, IAS 39 hedge accounting as an accounting policy when first adopting it - IASB, 2019, IFRS 9, paras. 7.2.21, BC6.104), airlines would be expected to have applied it due to the alleged fuel hedging benefits. In particular, it is reasonable to assume that airlines have designated hedges of component risk. The recognition of option time value, the forward element of forward contracts, and foreign currency basis spreads in OCI (IASB 2019, IFRS 9, paras. 6.5.15 to 16), which would also be expected to have been reclassified to OCI as required by IASB (2019), IFRS 9, para. 7.2.26, might have represented an additional incentive, as improving retained earnings. For some companies, however, this might have represented a disincentive to the adoption of IASB (2019), IFRS 
9 hedge accounting if gains have been reclassified from retained earnings to accumulated OCI.

As a second hypothesis to test, the adoption of IASB (2019), IFRS 9 hedge accounting would be expected to have resulted in more fuel hedge accounting quantities than before. IASB (2019), IFRS 9 would also be expected to have increased movements in OCI for cash flow hedges than previously, to the extent component risk hedges did not qualify as such under IASB (2014), IAS 39. There would also potentially be a greater hedge accounting offset in profit or loss and benefits to the bottom line.

However, it is difficult to test those hypotheses from financial statements data, as disclosures available do not generally permit to isolate the IASB (2019), IFRS 9 effect from business dynamics. In fact, it is not given to know, unless a company discloses it, how much of an increase in fuel derivatives as well as OCI movements can be attributed to the opportunity arisen from IASB (2019), IFRS 9 versus changes in hedging policies or business growth that may have required different hedge quantities. Furthermore, the carrying amount of derivatives assets and liabilities and the impact on OCI depends on fair value dynamics, which is affected by market factors. The extent of use of derivatives also depends on business cycle, fuel purchases, and risk management policies. In addition, while entities generally disclose the amount of OCI recycled to profit or loss, they do not necessarily show the gross amount of gain or loss in profit or loss that is offset by such a recycling. They do not necessarily show how much of fuel purchased amount is covered by hedged contracts, or they do not provide full details of how much of cash flow hedges relates to fuel hedges. Hedge ineffectiveness expensed in profit or loss would be also expected to be less, although this should be counterposed by the change in volume of cash flow hedges, so it would not prove to be meaningful as an indicator. It is also to be kept in mind that while risk component hedging is expected to reduce hedge ineffectiveness, the IASB has clearly explained that ineffectiveness might remain under risk component hedges (IASB 2019, IFRS 9, para. BC6.188).

Therefore, to the extent disclosed, the following parameters have been identified. The change in physical quantity or nominal amounts of fuel hedge contracts in the year of adoption of IASB, IFRS 9 from the previous year has been used as an indicator of the significance of fuel hedging for a company, also normalized against the change in revenue. Of course, this also has limitations, as the change in revenue reflects lots of other factors, including prices and other revenue items, so it only provides a reference point. Then, this indicator is partial, as a change in fuel hedging policies may also affect it. Some companies disclose, at least qualitatively, the new treatment of time value, forward points, and basis spread in OCI, which has also been captured as an indicator of the impact of adopting IASB (2019), IFRS 9 hedge accounting. Another indicator used, if disclosed, is the ratio of quantity or notional amount of fuel derivatives that have not been designated as hedging instruments versus those that have been designated as hedging instruments under IASB, IFRS 9 as compared with prior year, to see if such a weight has decreased after the adoption of the standard. IASB (2019), IFRS 9, paras. 7.2.22 and 7.2.24 require an entity to apply IASB (2019), IFRS 9 hedge accounting prospectively and to regard hedging relationships that qualify as such under both IASB (2014), IAS 39 and IASB (2019), IFRS 9 as continuing hedging relationships. IFRS Interpretations Committee (IFRIC) Update January 2016 confirmed that a change from an entire nonfinancial hedged item under IASB (2014), IAS 39 to a component of that nonfinancial hedged item is accounted for on transition on a prospective basis. The ratio of derivatives recognized in the statement of financial positions as derivatives not designated as hedging instrument for fuel would be expected to be lower in relation to derivatives designated as hedging instruments as compared with practice under IASB (2014), IAS 39.

The above analysis is conducted through a review of the financial statements, starting from the 53 sampled airlines used in Bellandi (2019). That sample considered the top 10 airlines by revenue, the top 10 airlines by passengers, top 10 U.S. airlines, and the top 10 European airlines. It then took the top 10 airlines of the survey of the World's Top 100 Airlines. Then, from the same survey it selected a random sample of at least 2 companies for each 10 rankings through random representation of the remaining population (e.g., at least 2 out of the companies ranking from 11 to 20, at least 2 from 21 to 30, etc.). To comprise companies ranked below 100, other companies were included. That initial sample has been modified to consider only IFRS preparers (given that this study is on IASB 2019, IFRS 9), and for the follows additional factors:

\begin{tabular}{l}
\hline \\
\hline $\begin{array}{l}\text { Initial sample (top } 10 \text { airlines by revenue, the top } 10 \text { airlines by passengers, top } 10 \text { U.S. airlines, and the top } 10 \text { European } \\
\text { companies }\end{array}$ \\
airlines, additional random sample) \\
Less: non-IFRS preparers (Air Asia, Air China, Hainan Airlines, Air India, Jet Airways, Garunda Indonesia, Aeroflot, \\
Alaska Air, Allegiant Airlines, American Airlines, Cargo Jet, Delta Air Lines, Hawaiian, JetBlue, Republic Airways, -18 \\
Southwest Airlines, Spirit Airlines, United Continental)
\end{tabular}




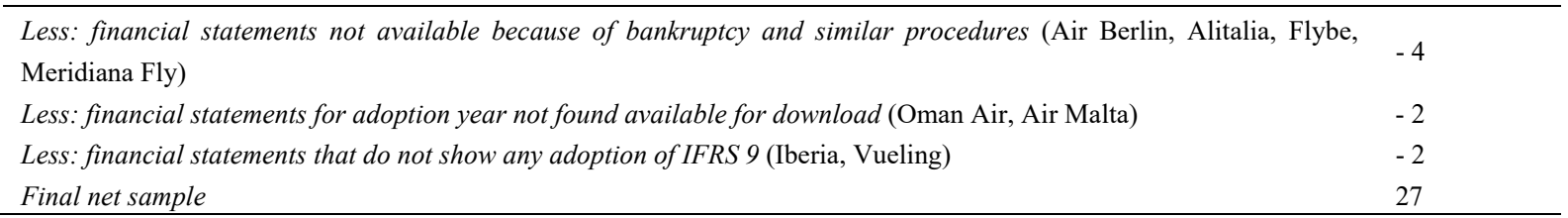

\section{Results and Discussion}

Table 1 shows whether the sampled companies have opted for the adoption of IASB, IFRS 9 hedge accounting, whether they have designated fuel risk components as the hedged risk, whether they have accounted for time value of option, forward points, or basis spread in OCI, and whether they have discussed the new standard hedge accounting as an opportunity.

$81 \%$ of the companies have applied IASB, IFRS 9 hedge accounting and only $7 \%$ have decided to remain under IASB (2014), IAS 39 hedge accounting, however without explaining why. Companies for a residual 12\% have not disclosed or did not have fuel hedges at transition date. From here it is evident that, although moving from IASB (2014), IAS 39 to IASB (2019), IFRS 9 may have transitional costs and administrative complexity, virtually all companies for which fuel hedging was important have decided to embrace IASB (2019), IFRS 9 on this respect.

$52 \%$ of the sampled companies have reported to have designated a risk component as fuel hedge risk for hedge accounting purposes, in conjunction with this new opportunity offered by the new standard. For $22 \%$ of companies the issue has been irrelevant as they either have not adopted IASB (2019), IFRS 9 hedge accounting or did not have any fuel hedges at transition date. Although more than the majority of companies have designated risk components, still a relevant portion of them $(26 \%)$ have not done so or provided information on this respect, which might be due to either their specific hedging strategies, or more time needed to get accustomed to IASB (2019), IFRS 9, or simply a failure to disclose.

$59 \%$ of companies have accounted for option's time value, forward points, or basis spread in OCI, while $26 \%$ have not done so or have not disclosed it. 14\% either have not adopted IASB (2019), IFRS 9 hedge accounting or did not have any fuel hedges at transition date.

$44 \%$ of the sampled companies have declared to see IASB (2019), IFRS 9 hedge accounting as an opportunity and have explained rationales in their narratives. The key reason given is that the new standard permits to designate component risk in line with risk management practice. Some companies have explained that their previous cash flow fuel hedging was based on component risk, but it was not reported in OCI as not accepted by IASB (2014), IAS 39 (e.g., Air Canada, Qantas), while with the new standard they have had an opportunity to reduce volatility in the income statement as well as to diminish the amounts recognized in profit or loss on non-designated derivatives. Some companies have claimed that before they had not used hedge accounting in situations affected by some of these limitations, or had designated the hedge item in its entirety, sometimes in conjunction with proxy hedging, i.e., designations of hedging relationships that do not exactly represent an entity's actual risk management, as per IASB (2019), IFRS 9, para. BC6.96 (e.g., Cathay Pacific, Finnair, Qatar). The second aspect explained for welcoming the new standard is the reporting in OCI of time value of option, forward points, or basis spread, which were previously excluded from hedge accounting. Finally, Wizz Air has explained that, by doing so, IASB (2019), IFRS 9 makes its previously used non-GAAP underlying profit measure no longer necessary, while Qantas has commented that it has reduced the difference from its underlying profit before tax. Some companies have added that IASB (2019), IFRS 9 might offer the use of additional underlying benchmarks to hedge an exposure to movements in the price of jet fuel, which would not have been possible under IASB (2014), IAS 39. As other points mentioned, the standard has less rules-based requirements for assessing hedge ineffectiveness and permits hedge ratio to be aligned to that used for risk management purposes (e.g., Cathay Pacific, China Southern, El Al Israel, Finnair, Qantas). Apart from companies that either have not adopted IASB, IFRS 9 hedge accounting or did not have any fuel hedges at transition date, $37 \%$ companies of the sample have not commented on the benefits of IASB (2019), IFRS 9 hedge accounting. In analyzing this basket, 15\% have designated component risk, although without explaining or emphasizing its benefits, while $19 \%$ have accounted for cost of hedging in OCI, but without commenting on its benefits.

In conclusion, IASB (2019), IFRS 9 hedge accounting has been adopted by a very large proportion of the sample and its new features have been exploited by most companies, although a definite explanation as an accounting strategy has been only partially explicated. 
Table 1. Adoption of IFRS 9 hedge accounting

\begin{tabular}{|c|c|c|c|c|}
\hline & $\begin{array}{l}\text { Adoption of IFRS } 9 \\
\text { Hedge Accounting }\end{array}$ & $\begin{array}{l}\text { Designation } \\
\text { Component Risk }\end{array}$ & $\begin{array}{l}\text { Option's Time Value, } \\
\text { Forward Points, Basis } \\
\text { Spread in OCI }\end{array}$ & $\begin{array}{l}\text { Does the Company Discuss } \\
\text { IFRS } 9 \text { Hedge Accounting } \\
\text { as an Opportunity? }\end{array}$ \\
\hline Aegean Airlines & No & No & No & No \\
\hline Air Arabia & Yes & N/A & Yes & Yes \\
\hline Air Canada & Yes & Yes & Yes & Yes \\
\hline Air France KLM & Yes & Yes & Yes & Yes \\
\hline Air Lingus & Yes & Yes & Yes & Yes \\
\hline British Airways & Yes & Yes & Yes & Yes \\
\hline Cathay Pacific & Yes & Yes & N/A & Yes \\
\hline China Eastern & $\begin{array}{l}\text { No fuel hedging for } \\
\text { accounting purposes } \\
\text { at transition date }\end{array}$ & $\begin{array}{l}\text { No, as fuel hedging for } \\
\text { accounting purposes at } \\
\text { transition date }\end{array}$ & $\begin{array}{l}\text { No, as fuel hedging for } \\
\text { accounting purposes at } \\
\text { transition date }\end{array}$ & $\begin{array}{l}\text { No, as fuel hedging for } \\
\text { accounting purposes at } \\
\text { transition date }\end{array}$ \\
\hline China Southern & Yes & $\mathrm{N} / \mathrm{A}$ & $\mathrm{N} / \mathrm{A}$ & No \\
\hline Comair & N/A & N/A & N/A & No \\
\hline EasyJet & Yes & N/A & Yes & No \\
\hline El Al Israel & Yes & Yes & Yes & Yes \\
\hline Emirates & Yes & $\begin{array}{l}\text { No, as fuel hedging for } \\
\text { accounting purposes at } \\
\text { transition date }\end{array}$ & $\begin{array}{l}\text { No, as fuel hedging for } \\
\text { accounting purposes at } \\
\text { transition date }\end{array}$ & $\begin{array}{l}\text { No, as fuel hedging for } \\
\text { accounting purposes } \\
\text { transition date }\end{array}$ \\
\hline EVA Air & Yes & Yes & N/A & No \\
\hline Finnair & Yes & Yes & Yes & Yes \\
\hline $\begin{array}{l}\text { International Airlines } \\
\text { Group }\end{array}$ & Yes & N/A & Yes & No \\
\hline Lufthansa Group & Yes & Yes & Yes & Yes \\
\hline $\begin{array}{l}\text { Norwegian } \quad \text { Air } \\
\text { Shuttle Asa }\end{array}$ & $\begin{array}{l}\text { No fuel hedging for } \\
\text { accounting purposes } \\
\text { at transition date }\end{array}$ & $\begin{array}{l}\text { No, as no fuel hedging } \\
\text { for accounting purposes } \\
\text { at transition date }\end{array}$ & $\begin{array}{l}\text { No, as no fuel hedging for } \\
\text { accounting purposes at } \\
\text { transition date }\end{array}$ & $\begin{array}{l}\text { No, as no fuel hedging for } \\
\text { accounting purposes } \\
\text { transition date }\end{array}$ \\
\hline Qantas & Yes & Yes & Yes & Yes \\
\hline Qatar Airways & Yes & Yes & Yes & Yes \\
\hline Ryanair & No & No & No & No \\
\hline SAS & Yes & N/A & Yes & No \\
\hline Singapore & Yes & Yes & Yes & No \\
\hline Turkish Airlines & Yes & Yes & No & No \\
\hline Virgin Australia & Yes & Yes & Yes & No \\
\hline West Jet & Yes & $\begin{array}{l}\text { No, as no fuel hedging } \\
\text { for accounting purposes } \\
\text { at transition date }\end{array}$ & $\begin{array}{l}\text { No, for other types of } \\
\text { hedging, the entire value is } \\
\text { designated as a hedging } \\
\text { instrument }\end{array}$ & $\begin{array}{l}\text { No, as no fuel hedging for } \\
\text { accounting purposes } \\
\text { transition date }\end{array}$ \\
\hline Wizz Air & Yes & N/A & Yes & $\begin{array}{l}\text { Yes, for making some } \\
\text { previously used non-GAAP } \\
\text { measure no longer necessary }\end{array}$ \\
\hline $\begin{array}{l}\text { N/A: Disclosure not } \\
\text { statements. }\end{array}$ & found in the financial & & & \\
\hline Yes & $81 \%$ & $52 \%$ & $59 \%$ & $44 \%$ \\
\hline $\begin{array}{l}\text { No, as no IFRS } 9 \\
\text { hedge accounting } \\
\text { adoption }\end{array}$ & $7 \%$ & $7 \%$ & $7 \%$ & $7 \%$ \\
\hline $\begin{array}{l}\text { No, as no fuel } \\
\text { hedging accounting } \\
\text { at transition date }\end{array}$ & $7 \%$ & $15 \%$ & $7 \%$ & $15 \%$ \\
\hline \multirow[t]{2}{*}{$\begin{array}{l}\text { No as a policy, or not } \\
\text { disclosed }\end{array}$} & $\underline{4 \%}$ & $\underline{26 \%}$ & $\underline{26 \%}$ & $\underline{33 \%}$ \\
\hline & $100 \%$ & $100 \%$ & $100 \%$ & $100 \%$ \\
\hline
\end{tabular}


Table 2 seeks quantitative indicators in the financial statements that may shed some light on the increase in significance of IASB (2019), IFRS 9 fuel hedging for airlines. As mentioned above, although it is difficult to find conclusive indicators, the ones identified give some partial indications. First, fuel cost stands out as a significant item of operating expenses ( $28 \%$ on average, ranging from $17 \%$ to $42 \%)$, for most airlines the biggest item. In terms of fuel derivatives quantity or nominal value designated for hedge accounting in the year of IASB, IFRS 9 adoption, $26 \%$ of the sampled companies have recorded an increase in fuel hedges more than proportional than the increase in revenue, $15 \%$ an increase in fuel hedges less than proportional than the increase in revenue, and $7 \%$ a change in the opposite direction. $22 \%$ are not significant because either they have not adopted IASB, IFRS 9 hedge accounting or they presented no fuel derivative at transition date. For $30 \%$ of companies, no data to assess this factor is available. $33 \%$ of companies have retrospectively reclassified equity for the cost of hedging for options time value, and 33\% have not made any reclassification. Depending on the company, reclassification of time value of option has not presented a unidirectional effect on retained earnings.

In summary, irrespective of whether a company decides to hedge, fuel cost results to be significant over total operating expenses, and consequently fuel risk exposure is key. Therefore, IASB (2019), IFRS 9 must be seen as an important standard in this respect. Although the dynamics of fuel derivatives quantity or nominal value do not provide any extremely strong evidence of IASB (2019), IFRS 9 hedge accounting as a driver of fuel hedging for accounting purpose, above indicators seem to show evidence that the standard has not provided an obstacle or has not been neutral.

Table 2. Effect of adoption of IFRS 9 hedge accounting

\begin{tabular}{|c|c|c|c|c|c|c|}
\hline & $\begin{array}{l}\text { Fuel/ Total } \\
\text { Operating } \\
\text { Expenses in } \\
\text { the Year of } \\
\text { IFRS } 9 \\
\text { Adoption }\end{array}$ & $\begin{array}{l}\text { Types of Fuel } \\
\text { Derivatives }\end{array}$ & $\begin{array}{l}\text { Change in Fuel } \\
\text { Derivatives } \\
\text { Quantity or } \\
\text { Nominal Value } \\
\text { Designated for } \\
\text { Hedge } \\
\text { Accounting in } \\
\text { the Year of } \\
\text { IFRS } \\
\text { Adoption }\end{array}$ & $\begin{array}{l}\text { Change in } \\
\text { Revenue in } \\
\text { the Year of } \\
\text { IFRS } 9 \\
\text { Adoption }\end{array}$ & $\begin{array}{l}\text { Ratio of Nominal Value of } \\
\text { Fuel Derivative Not } \\
\text { Designated/Designated } \\
\text { under IFRS } 9 \text { in the Year of } \\
\text { IFRS } 9 \text { Adoption vs. Prior } \\
\text { Year }\end{array}$ & $\begin{array}{l}\text { Equity } \\
\text { Reclassification } \\
\text { for Fuel Hedges } \\
\text { upon Adoption of } \\
\text { IFRS } 9\end{array}$ \\
\hline $\begin{array}{l}\text { Aegean } \\
\text { Airlines }\end{array}$ & $23 \%$ & $\begin{array}{l}\text { Futures, } \\
\text { swaps }\end{array}$ & No adoption & $\mathrm{N} / \mathrm{S}$ & $\mathrm{N} / \mathrm{S}$ & $\mathrm{N} / \mathrm{S}$ \\
\hline Air Arabia & $42 \%$ & $\begin{array}{l}\text { Commodity } \\
\text { swaps, } \\
\text { forward, } \\
\text { options and } \\
\text { others }\end{array}$ & $37.0 \%$ & $2.6 \%$ & N/A & 0 \\
\hline Air Canada & $20 \%$ & $\begin{array}{l}\text { Options and } \\
\text { swaps }\end{array}$ & $-16.0 \%$ & $4.5 \%$ & N/A & 0 \\
\hline $\begin{array}{l}\text { Air France } \\
\text { KLM }\end{array}$ & $33 \%$ & $\begin{array}{l}\text { Swap, call, } \\
\text { call spread, } \\
\text { three ways, } \\
\text { four ways and } \\
\text { collar }\end{array}$ & $12.1 \%$ & $2.5 \%$ & N/A & N/A \\
\hline Air Lingus & $22 \%$ & $\begin{array}{l}\text { Forwards and } \\
\text { swaps }\end{array}$ & $61.1 \%$ & $3.2 \%$ & N/A & N/A \\
\hline $\begin{array}{l}\text { British } \\
\text { Airways }\end{array}$ & $26 \%$ & $\begin{array}{l}\text { Options, } \\
\text { swaps, and } \\
\text { forwards }\end{array}$ & $60.0 \%$ & $61.1 \%$ & N/A & \begin{tabular}{lr}
\multicolumn{2}{l}{ Reclassification } \\
from (reduction \\
of) retained \\
earnings
\end{tabular} \\
\hline $\begin{array}{l}\text { Cathay } \\
\text { Pacific }\end{array}$ & $31 \%$ & Swaps & $-19.0 \%$ & $14.0 \%$ & N/A & 0 \\
\hline
\end{tabular}




\begin{tabular}{|c|c|c|c|c|c|c|}
\hline $\begin{array}{l}\text { China } \\
\text { Eastern }\end{array}$ & $33 \%$ & Options & $\begin{array}{l}\text { No fuel hedged } \\
\text { designated for } \\
\text { accounting } \\
\text { purposes in the } \\
\text { year of IFRS } 9 \\
\text { adoption }\end{array}$ & $\mathrm{N} / \mathrm{S}$ & $\mathrm{N} / \mathrm{S}$ & $\mathrm{N} / \mathrm{S}$ \\
\hline $\begin{array}{l}\text { China } \\
\text { Southern }\end{array}$ & $31 \%$ & N/A & $\mathrm{N} / \mathrm{A}$ & $\mathrm{N} / \mathrm{S}$ & $\mathrm{N} / \mathrm{A}$ & 0 \\
\hline Comair & $24 \%$ & N/A & N/A & $\mathrm{N} / \mathrm{A}$ & $\mathrm{N} / \mathrm{A}$ & 0 \\
\hline EasyJet & $24 \%$ & Forwards & $0.0 \%$ & $8.3 \%$ & N/A & $\begin{array}{ll}£ \quad 4 \quad M \\
\text { reclassification } \\
\text { within } \quad \text { OCI } \\
\text { reserves }\end{array}$ \\
\hline El Al Israel & $30 \%$ & Options & N/A & $\mathrm{N} / \mathrm{S}$ & $\begin{array}{l}\text { Before IFRS } 9 \text { some hedging } \\
\text { instruments were not } \\
\text { designated for accounting } \\
\text { purposes }\end{array}$ & 0 \\
\hline Emirates & $32 \%$ & $\begin{array}{l}\text { Futures, } \\
\text { options, and } \\
\text { swaps }\end{array}$ & $\begin{array}{l}\text { No fuel hedged } \\
\text { designated for } \\
\text { accounting } \\
\text { purposes in the } \\
\text { year of IFRS } 9 \\
\text { adoption }\end{array}$ & $\mathrm{N} / \mathrm{S}$ & $\mathrm{N} / \mathrm{S}$ & $\mathrm{N} / \mathrm{S}$ \\
\hline EVA Air & $\begin{array}{l}20 \% \text { on } \\
\text { inventory }\end{array}$ & $\begin{array}{l}\text { Swaps, } \\
\text { options, } \\
\text { forwards }\end{array}$ & N/A & $\mathrm{N} / \mathrm{S}$ & N/A & \begin{tabular}{lr}
\multicolumn{2}{l}{ Reclassification } \\
within & "other \\
equity" & OCI \\
reserves &
\end{tabular} \\
\hline Finnair & $19 \%$ & $\begin{array}{l}\text { Forwards, } \\
\text { options }\end{array}$ & $\begin{array}{l}14.4 \% \text { forwards, } \\
86.3 \% \text { options }\end{array}$ & $10.4 \%$ & N/A & \begin{tabular}{lr}
\multicolumn{2}{l}{ Reclassification } \\
from $\quad$ (reduction \\
of) & retained \\
earnings &
\end{tabular} \\
\hline $\begin{array}{l}\text { International } \\
\text { Airlines } \\
\text { Group }\end{array}$ & $25 \%$ & $\begin{array}{l}\text { Over the } \\
\text { counter } \\
\text { derivatives }\end{array}$ & $75.0 \%$ & $6.1 \%$ & & $\begin{array}{lr}€ 38 & \text { reclassified } \\
\text { from } & \text { (reduction } \\
\text { of) } & \text { retained } \\
\text { earnings } & \end{array}$ \\
\hline $\begin{array}{l}\text { Lufthansa } \\
\text { Group }\end{array}$ & $17 \%$ & Options & $12.3 \%$ & $0.8 \%$ & $5 \%$ vs. $64 \%$ prior year & $\begin{array}{l}\text { Reclassified to } \\
\text { (increase in) } \\
\text { retained earnings } \\
\text { Eur } 43 \mathrm{M}\end{array}$ \\
\hline $\begin{array}{l}\text { Norwegian } \\
\text { Air Shuttle } \\
\text { Asa }\end{array}$ & $38 \%$ & Forwards & $\begin{array}{l}\text { No fuel hedged } \\
\text { designated for } \\
\text { accounting } \\
\text { purposes in the } \\
\text { year of IFRS } 9 \\
\text { adoption }\end{array}$ & $\mathrm{N} / \mathrm{S}$ & $\mathrm{N} / \mathrm{S}$ & $\mathrm{N} / \mathrm{S}$ \\
\hline Qantas & $27 \%$ & $\begin{array}{l}\text { Options, } \\
\text { swaps }\end{array}$ & N/A & $\mathrm{N} / \mathrm{S}$ & N/A & 0 \\
\hline $\begin{array}{l}\text { Qatar } \\
\text { Airways }\end{array}$ & $32 \%$ & $\begin{array}{l}\text { Swaps and } \\
\text { options }\end{array}$ & N/A & $\mathrm{N} / \mathrm{S}$ & N/A & $\begin{array}{lr}\mathrm{K} \quad 93 & \mathrm{QR} \\
\text { reclassified } & \text { from } \\
\text { (reduction } & \text { of) } \\
\text { retained earnings }\end{array}$ \\
\hline Ryanair & $35 \%$ & $\begin{array}{l}\text { Swaps and } \\
\text { forwards }\end{array}$ & No adoption & $\mathrm{N} / \mathrm{S}$ & $\mathrm{N} / \mathrm{S}$ & $\mathrm{N} / \mathrm{S}$ \\
\hline
\end{tabular}




\begin{tabular}{|c|c|c|c|c|c|c|}
\hline SAS & $21 \%$ & $\begin{array}{l}\text { Options and } \\
\text { swaps }\end{array}$ & $18.3 \%$ & $4.5 \%$ & N/A & $\begin{array}{lr}\text { SEK } 20 & \text { M } \\
\text { reclassified } & \text { to } \\
\text { (increase } & \text { in) } \\
\text { retained earnings }\end{array}$ \\
\hline Singapore & $31 \%$ & $\begin{array}{l}\text { Swaps, } \\
\text { options, and } \\
\text { collars }\end{array}$ & N/A & $\mathrm{N} / \mathrm{S}$ & N/A & N/A \\
\hline Turkish & $32 \%$ & $\begin{array}{l}\text { Forwards and } \\
\text { collars }\end{array}$ & N/A & $\mathrm{N} / \mathrm{S}$ & N/A & 0 \\
\hline $\begin{array}{l}\text { Virgin } \\
\text { Australia }\end{array}$ & $20 \%$ & $\begin{array}{l}\text { Swaps, } \\
\text { options, and } \\
\text { others }\end{array}$ & $0.2 \%$ & $7.5 \%$ & N/A & 0 \\
\hline West Jet & $27 \%$ & $\mathrm{~N} / \mathrm{A}$ & $\begin{array}{l}\text { No fuel hedged } \\
\text { designated for } \\
\text { accounting } \\
\text { purposes in the } \\
\text { year of IFRS } 9 \\
\text { adoption }\end{array}$ & $\mathrm{N} / \mathrm{S}$ & $\mathrm{N} / \mathrm{S}$ & $\mathrm{N} / \mathrm{S}$ \\
\hline Wizz Air & $29 \%$ & $\begin{array}{l}\text { Forwards, } \\
\text { collars }\end{array}$ & $4.7 \%$ & $24.0 \%$ & N/A & $\begin{array}{lr}\text { E6.1 M reclassified } \\
\text { from } \quad \text { (reduction } \\
\text { of) retained } \\
\text { earnings }\end{array}$ \\
\hline
\end{tabular}

N/A: Disclosure not found in the financial statements. N/S: Not significant.

$\begin{array}{ll}\text { Average } & 28 \% \\ \text { Max } & 42 \% \\ \text { Min } & 17 \%\end{array}$

Increase in fuel hedges more than proportional than increase in revenue

Increase in fuel hedges less than proportional

than revenue

Less fuel hedges, more revenue

No IFRS 9 adoption

$\begin{array}{ll}7 \% & 7 \% \\ \% & 15 \%\end{array}$

$11 \%$

Reclassification from (reduction of) retained earnings

Reclassification to (increase in) retained earnings

Reclassification within OCI reserves

The findings of this article complement the relevant literature to enrich scholarly knowledge about this research topic. In fact, there is insufficient investigation of the impact of IFRS 9 on fuel hedging practice, while this topic is the crux of this study. Readers can benefit from this study to understand how companies have reacted to the new standard in their fuel hedges and whether they have understood and applied the new opportunities offered. As a driver of fuel hedging for accounting purpose, entities could study how IFRS 9 can help better articulate accounting strategy for fuel hedging, possibly extending that approach to their risk management at large. Through additional focused surveys, researchers can expand the conclusions of this article by interacting with management on the specific angles investigated in this article.

\section{References}

Bellandi, F. (2019). Leased Aircraft Maintenance Reserves: Comprehensive Framework to Unsolved Issues under IFRS 16 and Topic 842. International Journal of Business and Management, 14(11), 27-54. https://doi.org/10.5539/ijbm.v14n11p27

Bernhardt, T., Erlinguer, D., \& Unterrainer, L. (2016). IFRS 9: The New Rules for Hedge Accounting from the 
Risk Management's Perspective. Oxford Journal of Finance and Risk Perspectives, 53(3), 1-14. Retrieved from http://www.acrn-journals.eu/resources/jofrp0503a.pdf

Carter, D. A., Rogers, D. A, \& Simkins, B. J. (2006), Hedging and Value in the U.S. Airline Industry. Journal of Applied Corporate Finance, 18(4), 21-33. https://www.doi.org/10.1111/j.1745-6622.2006.00107.x

Cominskey, E. E., \& Mulford, C. W. (2008). The Non-Designation of Derivatives as Hedges for Accounting Purposes. The Journal of Applied Research in Accounting and Finance, 3(2), 3-16. Retrieved from https://www.researchonline.mq.edu.au/vital/access/services/Download/mq:10333/DS01?view=true

Duran, A., \& Gungor, M. S. (2017). Aviation Fuel Hedging and Firm Value Analysis Using Dynamic Panel Data Methodology: Evidence from the U.S. Major Passenger Airlines. International Journal of Business and Economic Sciences Applied Research, 10(3), 67-72. https://doi.org/10.25103/ijbesar.103.04

Financial Accounting Standards Board. (2017). Accounting Standards Update No. 2017-12. Derivatives and Hedging (Topic 815): Targeted Improvements to Accounting for Hedging Activities, (ASU 2017-12). Retrieved from http://www.fasb.org

Financial Accounting Standards Board. (2020). FASB Accounting Standards Codification (FASB ASC). Retrieved from http://www.fasb.org

Glaum, M., \& Klöcker. (2011). Hedge Accounting and Its Influence on Financial Hedging: Evidence from Germany and Switzerland. Accounting and Business Research, 41(5), 459-489. https://doi.org/10.1080/00014788.2011.573746

Hoon Lim, S., \& Hong, Y. (2014). Fuel Hedging and Airline Operating Costs. Journal of Air Transport Management, 36, 33-40. https://www.doi.org/10.1016/j.jairtraman.2013.12.009

Hoon Lim, S., \& Turner, P. A. (2016). Airline Fuel Hedging: Do Hedge Horizon and Contract Maturity Matter? Journal of the Transportation Research Forum, 55(1), 29-49. https://dx.doi.org/10.5399/osu/jtrf.55.1.4325

IFRS Interpretations Committee. (2016). IFRIC Updates. Retrieved from http://www.ifrs.org

International Accounting Standards Board. (2014). International Accounting Standard 39. Financial instruments: Recognition and Measurement - as amended (IAS 39). Retrieved from http://www.ifrs.org

International Accounting Standards Board. (2019). International Financial Reporting Standard 9. Financial instruments - as amended (IFRS 9). Retrieved from http://www.ifrs.org

Korkeamäki, T., Liljeblom, E., \& Pfister, M. (2016). Airline Fuel Hedging and Management Ownership. Journal of Risk Finance, 17(5), 492-509. https://doi.org/10.1108/JRF-06-2016-0077

Morell, P., \& Swan, W. (2006). Airline Jet Fuel Hedging: Theory and Practice. Transport Review, 26(6), 713-730. https://doi.org/10.1080/01441640600679524

Trempski, R. (2009). Does Fuel Hedging Add Value? Quantitative Analysis but Qualitative Conclusion in the Case of the US Airline Industry. Undergraduate Economic Review, 5(1). Retrieved from https://digitalcommons.iwu.edu/uer/vol5/iss1/9

\section{Copyrights}

Copyright for this article is retained by the author(s), with first publication rights granted to the journal.

This is an open-access article distributed under the terms and conditions of the Creative Commons Attribution license (http://creativecommons.org/licenses/by/4.0/). 